\title{
Awareness and Readiness of Librarians towards the Use of Social Media for Information Service Delivery in Higher Institutions of Learning in Bauchi State
}

\author{
Asma'u Muhammad Yusuf \\ Bauchi State University Gadau, Library, Nigeria \\ E-mail: asmaumuhammadyusuf2017@gmail.com \\ Tel: +23407015321266
}

\begin{abstract}
This paper examines the librarians' awareness of social media, types of social media used by librarians, perception and readiness of librarians towards the use of social media, the level of use of social media and factors facilitating the use of social media in higher institutions library in Bauchi state. The rationale behind the subject matter (social media) was to expose librarians to the potentials of the use of social media in the library, particularly with regards to effective and efficient information service delivery to meet the ever growing demands and needs of sophisticated users. In doing this, quantitative research methodology using crosssectional survey design was used which helped the researcher gather large amount of data that can be easily organised and manipulated into reports for analysis. A well developed and structured questionnaire was used to generate data from the respondents.
\end{abstract}

Keywords: Awareness and Readiness, Librarians, Social Media, Information Service, Higher Institutions, Bauchi State.

\section{Introduction}

The concept of a library as a physical place where one can visit to get information is rapidly changing to a social cyberspace where users access information, communicate and contribute to existing knowledge. The social media has gradually crept into the library profession which has become a growing tool that is being used to communicate with more potential library users; extending and offering better services to users. In view of this, Tise (2009) stated that the social media is a new model of online services that encourages an increased flow of information from the library to users and from users back to the library.

Libraries by their orientation are service providers; the satisfaction of the clientele has always been their objectives and goals. Thus, the library provides various types of resources and services in order to meet up with the needs of its users. Nevertheless, these resources are selected, acquired, organized and stored for the purpose of meeting up with its user's information needs. Academic libraries are one of those numerous types of libraries that exist in the information world. In view of this, Edoka (2000) defined academic libraries as "libraries that are found in most institutions of higher learning such as polytechnics, colleges of education and universities". He maintained that librarians are in charge of higher learning institutions' libraries; they perform and render different kinds of services to its users still in the old traditional way.

With advancement in technology, librarians are now turning to social media for information service delivery of their clientele and also to meet up their professional needs and demands. Therefore, social media offers boundless opportunities that are highly valued for their ability to connect libraries with users who may be unaware of their existence. Thus, providing specialized information service delivery. Mathews (2006, 2008) suggested that librarians can create services that are more responsive and attuned to the changing needs of users. In the same vein Sadeh (2007) argued that making social media presence remains pertinent and fundamental to meet users' expectations particularly the younger ones. Therefore, to effectively deploy these social media for information service delivery, librarians must be versatile and knowledgeable in different subject fields to be able to match patrons with desired information.

On this note, social media tools have become a veritable means of communication in the world today, and there is need for librarians to equip themselves with skills needed to meet up with the demands of their sophisticated users. In addition, the social and communication needs of our society have changed by the influx of the social media, and the users of the library facilities have seen social media as indispensible tool for them because of its versatility in accessing the required information which is made very much easier for them. There is therefore, a foremost challenge before the librarians to face the needs of the user in current ICT environment and to provide access to all relevant information and integrate it on networks across the world. As such, librarians need to acquire new modern knowledge for competencies, as information professionals, more is expected of them from their users in order to maintain competitive edge, efficiency and work effectively in the rapid changing environment they found themselves (Onuoha, 2013). 


\section{Literature Review}

Social media, social networking, online communication are words used interchangeably. According to Kaplan and Haenlein (2010) social media refers to a group of internet based applications that build on the ideological and technological foundations of Web 2.0. They maintained that such applications allow users to interact freely, share and discuss information using multimedia mix of words, pictures, videos, and audio. In other words, social media denote an interaction among people in which they create, share and exchange information and ideas in virtual communities and networks.

Zakaria, Watson and Edward (20I0) cited in Parveen (20II) stated that social media applications have already been accepted by young generations as a platform to socialize, collaborate and learn in an informal and flexible manner although their level of involvement and contribution varies significantly. Al-Daihani's study (2010) explores that the majority of Library and Information Science (LIS) students are aware of social media applications and are making moderate use of Blogs, communication tools and social networking sites.

\section{I Importance and Awareness of Social Media}

Social media has become a level playing ground for academics and students to interact on issues pertaining to course work. Students also use this platform to share information amongst themselves on any subject and topic. Bell (2007) found that "academic libraries do not only use social media for communication purposes, but had adapted their research strategies to this environment”. In the same view, Ayiah and Kumah (20II) stated the importance of social media to librarians and clients is that "social media will facilitate the collaborations and promote effective communication between librarians and their patrons. It will generate a flow of information excluded from search engines and library catalogue". This statement conforms to what is obtainable especially in libraries of developed societies who have already incorporated and harness social media into their library services for effective information service delivery, but quite a gap in Nigerian context, as librarians are still yet to tap the full potentials of social media for information service delivery. This is evident in the preliminary study conducted by the researcher, where most of the libraries visited have not made their libraries visible on social media.

Scales (2008) shared the same view where he found out that social media will lead to a future service delivery of information to meet search queries- the crucial aim of library and librarian is to make library resources available to patrons, so if social media tools will help achieve this goal then it should be pursued vigorously. In this sense, social media wall linked to a library's web page has the potential of reaping great results by attracting and serving distant users. Also Watts, Dodds and Newman (2002) stated that it is through social media tools that the librarian is capable of communicating and disseminating information to a broad audience. It will help African librarians and libraries to keep pace with technologies and compete with developed world.

The significance of social media cannot be over emphasized. It is a platform through which the library and or the librarian can know about its image to see the possibilities for improvement (Nicholas, Watkinson, Rowlands \& Jubb, 20II). This argument is supported by Barwise and Meehan (2010) where they stated the significance of social media such as building reputation and credibility, monitoring what users are saying and building of user relations through interaction. Social media can also facilitate communication and engagement.

Social media is a robust communication tool and information resource that has literally transformed our society and the way we discuss. One of the purposes of using the social media is in its efficiency in communication where one communicates to millions of users at a point in time. For example, Romero (201 I) stated that due to the concise format and informal tone, social media such as Blogs can stir up interactions between users and librarians. Scholars concluded that social media can advance communication in quantity and may improve in quality (Stuart, 2010).

From the discussion above, it is evident that while some librarians have low awareness of social media, others have significant awareness though they do not implement the media for information service delivery. In the context of Nigeria, the study conducted by Ezeani and Igwesi (2012) has confirmed that due to inadequate infrastructures, facilities, skills and negative attitude of librarians towards technology, librarians' level of social media awareness as a tool for information service delivery is significantly low. Even though most of the libraries have internet connections, all of the librarians do not use any of the social media for the purpose of information service delivery. Further survey conducted by Marshall (2009) to assess the awareness of social media tools (Wikis, Blogs) among library and information science professionals found that LIS professionals of colleges are well aware of the modern concept and also make use of them. But they implement it very less as far as rendering or library services are concerned (Thanuskodi, 20II).

However, the literatures have stated that librarians are well aware of social media even though they hardly use or implement them. While other librarians are aware of some social media tools, but don't have knowledge of others.

\section{Methodology}

As far as this study is concerned, survey research design, using cross- sectional survey design, was employed, the target population of the study comprises all 10 higher institutions of learning in Bauchi state, Having stated the target population, the accessible 
population therefore comprised of sixty nine (69) librarians in the academic libraries of the higher institutions in the state. Due to the number of population in the study which was sixty nine (69) librarians, the researcher used all the librarians because the population was not much and was conveniently managed.

\section{Findings and Discussion}

A total of sixty nine (69) questionnaires were distributed to academic librarians in higher institution under study. Only sixty three (63) were completed and returned. The respondent stated as follows:

I Response Rate

TableI. Response Rate

\begin{tabular}{lcc}
\hline Questionnaire & Frequency & Percentage (\%) \\
\hline Number of questionnaire administered & 69 & I00 \\
\hline Number of questionnaire returned & 63 & 91.3 \\
\hline Number of questionnaire not returned & 06 & 8.7 \\
\hline
\end{tabular}

Table-I shows that 69 copies of questionnaire were administered to the respondents, out of which 63 (9I.3\%) were filled, returned and found useful. While $12(8.7 \%)$ were not returned. The high rate of returned copies of the questionnaire was attributed to the fact that the respondents are within the reach of the researcher.

Awareness of the Social Media

Table 2. Social Media Awareness

\begin{tabular}{ccc}
\hline Social Media Awareness & Frequency & Percentage (\%) \\
\hline Yes & 63 & I00 \\
\hline No & 0 & 0 \\
\hline Total & 63 & Level of Awareness \\
\hline & 9 & 100.0 \\
\hline Not sure & 40 & 63.5 \\
\hline High & 14 & 22.2 \\
\hline Very high & 63 & 100.0 \\
\hline Total & Source of Awareness & \\
\hline & 26 & 41.3 \\
\hline Colleagues & 10 & 15.9 \\
\hline Library & 15 & 23.9 \\
\hline Friends/ Family & 10 & 15.9 \\
\hline Workshop/ Conference & 2 & I00.0 \\
\hline Others & 63 & \\
\hline Total & & \\
\hline
\end{tabular}

Table 2 shows that all (91.3\%) respondents indicated that they have awareness of the social media. On the level of awareness the table also shows that majority, 40(63.5\%) of the respondents rate their level of awareness with the social media to be high. The findings on awareness of social media and level of awareness cannot be detached from the popularity of social media among users. Further justification is the primary features of the social media; easy to use and convenient.

Table 2 further presents the librarian's source of awareness of the social media; majority, 26(4I.3\%) of the respondents indicated that they got their awareness from colleagues followed by family and friends with $15(23.9 \%)$, library had IO(I5.9\%), while workshop and conferences had also IO(I5.9\%). The finding on the sources of awareness of social media reveals that social media is widely discussed at various and different levels among family and friends, colleagues, at workshops/conferences, and the library. 
Table 3. Awareness of the types of Social Media

\begin{tabular}{|c|c|c|c|}
\hline \multirow[t]{2}{*}{ Social media } & \multicolumn{2}{|c|}{ Frequency/Percentage (\%) } & \multirow[t]{2}{*}{ Total } \\
\hline & Yes I am aware & No I'm not aware & \\
\hline Twitter & $50(79.4 \%)$ & I3(20.6\%) & $63(100 \%)$ \\
\hline Linkedin & $43(68.3 \%)$ & $20(\% 31.7)$ & $63(100 \%)$ \\
\hline YouTube & $61(97 \%)$ & $2(3 \%)$ & $63(100 \%)$ \\
\hline Facebook & $52(89 \%)$ & $12(19 \%)$ & $63(100 \%)$ \\
\hline MySpace & $44(70 \%)$ & $19(30 \%)$ & $63(100 \%)$ \\
\hline Ning & $18(28.6 \%)$ & $45(71.4)$ & $63(100 \%)$ \\
\hline Wikis & $10(16 \%)$ & $53(84 \%)$ & $63(100 \%)$ \\
\hline Blogs & $27(43 \%)$ & $36(57 \% 0$ & $63(100 \%)$ \\
\hline Flickr & $08(12.7 \%)$ & $55(87.3)$ & $63(100 \%)$ \\
\hline $\begin{array}{l}\text { Social } \\
\text { gaming }\end{array}$ & $05(8 \%)$ & $58(92 \%)$ & $63(100 \%)$ \\
\hline Others & $07(\mathrm{II.1} \%)$ & $56(88.9 \&)$ & $63(100 \%)$ \\
\hline
\end{tabular}

Respondents were asked to indicate the types of social media they were aware of. The findings from table 3 show that the following percentages: $52(89 \%), 50(79.4 \%), 45(68.3 \%), 61(97 \%)$ represent that majority have indicated their awareness of Facebook, Twitter LinkedIn and YouTube respectively. The finding implies that the librarians under study are more aware of certain social media applications than others. This could be attributed to the lack of knowledge of the different types of social media available, coupled with the fact that other types are just emerging; therefore awareness of such social media tools is very low. This corroborates with Adaja and Ayodele (2013) who asserted that Facebook and Twitter are the most popular of social media, although new social media tools are emerging they are however not commonly used.

Table 4. Source of Access

\begin{tabular}{ccc}
\hline Source & Frequency & Percentage (\%) \\
\hline Phone & 35 & 55.6 \\
\hline Computer & 20 & 31.7 \\
\hline IPad & 08 & 12.7 \\
\hline Total & 63 & 100 \\
\hline
\end{tabular}

Table 4 shows that majority 35(64.2\%) of the respondents accessed the social media through their phones. The finding of the phone being the major source of access among librarians is related to the fact that phones are portable, affordable, easier to use and have features that access the internet (Kim and $\operatorname{Sin}, 2007$ ). IPad with 08(I2.7\%) respondents selecting it was the least used source of accessing the social media. This could be as a result of the fact that IPad is not affordable to all when compared with phone and computer.

\section{Conclusion}

The librarians in higher institutions of learning in Bauchi state are aware of social media and they use different types of social media particularly Facebook, YouTube, and Twitter. The social media is an important and useful tool for communication and collaboration with users, dissemination of information, marketing and reference services, bibliographic services etc. Therefore the librarians have a positive perception and are ready and prepared to use the new technology for service delivery.

However, the findings have indicated that librarians are well aware of social media even though they hardly use or implement them. While other librarians are aware of some social media tools, but don't have knowledge of others.

\section{References}

Adaja, T. A., \& Ayodele, F. A. (2013). Nigerian youths and social media: Harnessing the potentials for academic excellence. Singaporean Journal of Business, Economics and Management Studies, 5I(I I08), I-I I.

Al-Daihani, S. (2010). Exploring the use of social software by master of library and information science students. Library Review, 59(2), II7-I3I.

Barwise, P., \& Meehan, S. (2010). The one thing you must get right when building a brand. Harvard business review, 88(I2). Bell, S. J. (2007). Building better academic libraries with Web 2.0 technology tools. Library Issues, $28(2)$, I-4.

Edoka, B. E. (2000). Introduction to Library Science. Onitsha. Palma Publishing, J. Acad. Lib, 20, 5I7-532. 
Ezeani, C. N., \& Igwesi, U. (2012). Using social media for dynamic library service delivery: The Nigeria experience. Library Philosophy and Practice, I.

Hafiz Zakaria, M., Watson, J., \& Edwards, S. L. (2010). Investigating the use of Web 2.0 technology by Malaysian students. Multicultural Education \& Technology Journal, 4(I), 17-29.

Kaplan, A. M., \& Haenlein, M. (2010). Users of the world, unite! The challenges and opportunities of Social Media. Business horizons, 53(I), 59-68.

Marshall, B. (2009).Social networking strategies for professionals, Computers in Libraries, 29 (9).

Mathews, B. (2008). Twitter and the library: Thoughts on the syndicated lifestyle. Journal of web Librarianship, 2(4).

Mathews, B.(2006). Do you Facebook? Networking with student's online.College and research Libraries, 67(5).

Nicholas, D., Watkinson, A. Rowlands, I. \&Jubb, M. (20II). Social Media, Academic Research and the Roleof University Libraries. The Journal of Academic Librarianship, 37(5).

Onuoha, U. D. (2013). Librarians' Use of 'Social Media for Professional Development in Nigeria. Information Management and Information Business Review, 5(3).

Parveen, N. (20I I).Use of Social Networking Site (Facebook) in Making Awareness Among The Library And Information Science Professional of University of U.P: A Case Study”. International Journal of Digital Library Services.I(I).

Romero, N.L. (20II). ROI. Measuring the social media return on investment in a library. The Bottom Line: Managing Library Finances, 24(2).

Sadeh, T. (2007) Time for a Change: New approaches for a new generation of library users. New Library World, I08(7/8).

Scale, M. S. (2008). Facebook as a social search engine and the implications for libraries in the twenty-first century. Library Hi Tech, $26(4), 540-556$.

Stuart, D. (2010). What are libraries doing on Twitter?. Online, 34(I), 45-47.

Thanuskodi, S. (20I0). WEB 2.0 awareness among library and information science professionals of the engineering colleges in Chennai City: A survey. Journal of Communication, I(2), 69-75.

Tise, E. R. (2009). Acceptance speech delivered at the 75th IFLA Congress in Milan, 2009.

Watts, D. J., Dodds, P. S., \& Newman, M. E. (2002). Identity and search in social networks. science, 296 (557I), I302-I305.

\section{Copyrights}

Copyright for this article is retained by the author(s), with first publication rights granted to the journal. This is an open-access article distributed under the terms and conditions of the Creative Commons Attribution license (http://creativecommons.org/licenses/by/4.0/). 